\title{
PENGARUH DUKUNGAN SUAMI DENGAN MOBILITAS PEKERJAAN TINGGI DAN SIKAP IBU HAMIL TERHADAP TES HIV DI PUSKESMAS NAMORAMBE WILAYAH KABUPATEN DELI SERDANG
}

\author{
Masta Melati Hutahaean', Eka Ristin Tarigan² \\ 1,2 STIKes Murni Teguh \\ e-mail: mastahutahaean020101@gmail.com
}

DOI : https://doi.org/10.35451/jkk.v2i1.242

\begin{abstract}
The government is starting to state housewives as the HIV protection targets, including pregnant women, considering the increasing of the risk of HIV transmission in the low risk groups including mothers and infants. Based on the Ministry of Health (2017) the percentage of pregnant women that taking an HIV test in Deli Serdang District is only around 0.33\%. This study is addressed to analyze the effect of husband support with high occupational mobility and attitudes of the pregnant women towards HIV testing at Namorambe Health Center, Deli Serdang District. This type of research is an observational analytic study with a case control design. The population in this study were all pregnant women who came for their prenatal care and had received counseling for HIV testing at the Namorambe Health Center. The sample is 31 cases and 31 controls. Univariate and bivariate analysis with chi square test.The results showed that attitude (OR: 8,196; 95\% CI = 2,311-29,073) influenced the participation of HIV testing while husband's support did not affect the participation of HIV testing at the Namorambe Health Center in Deli Serdang District.It is recommended for health workers to make efforts to improve the positive attitude of pregnant women to be more empowered and aware of the vulnerability of contracting HIV, especially in mothers with high husband's work mobility so that they can make the right decisions related to prevention of HIV transmission from mother to baby through HIV testing even though they have not received support from husband.
\end{abstract}

Key Words: Infuence, Attitude, Husband's Support, High Mobility, HIV Test

\section{Pendahuluan}

HIV merupakan penyakit menular yang disebabkan human immunodeficiency virus yang menjadi ancaman kesehatan serius masyarakat global. HIV dapat terinfeksi secara vertikal dari ibu HIV positif yang dideteksi melalui tes HIV kepada bayi pada masa kehamilan, persalinan dan menyusui yang saat ini mendapat 
sorotan dunia karena berpengaruh terhadap kualitas sumber daya manusia. Prevalensi HIV/AIDS di Sumatera Utara 28,97/100.000 penduduk, menempati posisi ketujuh dengan persentase kumulatif hingga Maret 2017 sebesar 5,54\%. Jumlah kasus HIV tahun 2017 di Sumatera Utara yaitu 477 kasus dan 56 kasus terjadi Kabupaten Deli Serdang. Trend kasus infeksi HIV mayoritas terjadi pada kelompok umur 25-49 tahun (69,6\%). Mempertimbangkan hal tersebut maka potensi ancaman besar terjadi pada kelompok wanita usia produktif seiring dengan semakin meningkatnya kasus HIV pada ibu rumah tangga (14,8\%) yang bila hamil berpotensi menularkan HIV ke bayinya (Kemenkes R.I, 2018).

Pemerintah mulai menjadikan ibu rumah tangga sebagai sasaran proteksi HIV termasuk ibu hamil, mengingat meningkatnya resiko penularan HIV pada kelompok resiko rendah termasuk ibu dan bayi. Hal ini ditegaskan dalam agenda pembangunan dunia SDGs khususnya goals ketiga lebih jauh menekankan pada kesehatan ibu dan anak yang menjadi daya ungkit dasar dalam menentukan keberhasilan SDGs termasuk penanggulangan HIV yang dideteksi melalui tes diagnostik serologi (Permenkes R.I, 2017) .

Penelitian Aggleton, et.al (2014) menunjukkan kerentanan dan risiko HIV erat kaitannya dengan "mobile men with money" mengacu pada laki-laki dalam konteks pergerakan (mobilitas) pekerjaan tinggi dengan uang dan merupakan kategori risiko terbaru yang digunakan negara-negara Asia, Pasifik dan Afrika sebagai "populasi paling berisiko" atau membuat orang lain termasuk pasangan rentan terinfeksi HIV.

Berdasarkan Kemenkes (2017) dari 340.294 ibu hamil yang ada di Sumatera Utara diketahui bahwa hanya 1.136 ibu hamil yang melakukan tes HIV di Kabupaten Deli Serdang (0,33\%), 1 diantaranya positif HIV. Berdasarkan hasil wawancara terhadap 10 orang ibu hamil yang melakukan ANC di Puskesmas Namorambe Kabupaten Deli Serdang, 4 orang menyatakan telah mengikuti tes HIV dan 6 orang lainnya menyatakan masih menunda pemeriksaan karena belum ijin kepada suami. Masih rendahnya keikutsertaan ibu untuk melakukan tes HIV terutama karena ibu masih terfokus pada suami sebagai pengambil keputusan terkait dengan tes HIV menyebabkan seakan pelaksanaan Pencegahan Penularan dari Ibu ke Anak (PPIA) terkesan lambat.

Hal inilah yang melatarbelakangi penelitian ini dilakukan yaitu untuk menganalisa pengaruh dukungan suami dengan mobilitas pekerjaan tinggi dan sikap ibu hamil terhadap tes HIV di Puskesmas Namorambe Kabupaten Deli Serdang.

\section{METODE PENELITIAN}

Penelitian menggunakan desain case control. Populasi target penelitian adalah seluruh ibu hamil yang datang memeriksakan kehamilannya ke Puskesmas Namorambe Kabupaten Deli Serdang dan telah mendapat konseling untuk tes HIV. Sampel berjumlah 62 ibu hamil yang terdiri dari 31 kasus dan 31 kontrol dimana yang menjadi kelompok kasus yaitu ibu hamil yang tidak melakukan tes HIV dan kelompok kontrol yaitu ibu hamil yang telah melakukan tes HIV. Sampel penelitian diambil secara purposive sampling. Dalam penelitian ini pertimbangan tertentu tersebut berdasarkan kriteria kasus dan kontrol pada saat berkunjung yaitu telah mengikuti konseling tes HIV dan mendapat anjuran dari tenaga kesehatan untuk tes HIV, suami dengan mobilitas pekerjaan yang tinggi baik antar desa maupun antar pulau dan dalam jangka waktu yang tertentu dan bersedia berpartisipasi dalam penelitian.

Data dikumpulkan dengan menggunakan kuesioner yang telah teruji validitas dan reliabilitasnya. Analisis data menggunakan analisis univariat dan bivariat dengan uji chisquare. 


\section{HASIL}

Sosiodemografi responden.

Responden yang tidak melakukan tes HIV mayoritas berusia $\leq 35$ tahun $(96,8 \%)$, berada pada trimester I $(38,7 \%)$, mayoritas responden bekerja $(51,6 \%)$, paritas $>1(83,9 \%)$ dan kunjungan ANC dengan frekuensi $\geq 2$ $(90,3 \%)$. Sedangkan responden yang melakukan tes HIV mayoritas berusia $\leq$ 35 tahun $(93,5 \%)$, tingkat pendidikan lanjutan $(80,6 \%)$, mayoritas responden tidak bekerja $(54,8 \%)$, paritas $>1$ $(80,6 \%)$ dan kunjungan ANC dengan frekuensi $\geq 2(90,3 \%)$ (Tabel 1$)$.

Sikap responden. Responden yang tidak melakukan tes HIV mayoritas memiliki sikap kurang baik (54,8\%). Sedangkan responden yang melakukan tes HIV mayoritas responden memiliki sikap baik $(87,1 \%)$ (Tabel 1$)$.

Dukungan suami. Responden yang tidak melakukan tes HIV mayoritas memiliki dukungan suami baik $(51,6 \%)$. Sebanding dengan responden yang melakukan tes HIV mayoritas juga memiliki dukungan suami yang baik $(61,3 \%)$ (Tabel 1).

$\begin{array}{lcr}\text { Pengaruh } & \text { sikap } & \text { terhadap } \\ \text { keikutsertaan } & \text { tes HIV. Hasil }\end{array}$ penelitian menunjukkan ada pengaruh sikap terhadap keikutsertaan tes HIV dengan OR sebesar 8,196 yang berarti bahwa ibu yang tidak melakukan tes HIV perkiraan peluangnya 8,196 kali memiliki sikap kurang baik dibandingkan dengan ibu hamil yang melakukan tes HIV (Tabel 1).

\section{Pengaruh dukungan suami terhadap keikutsertaan tes HIV. Hasil penelitian menunjukkan tidak ada pengaruh dukungan suami terhadap keikutsertaan tes HIV dengan dengan $p$ value 0,608 , diketahui bahwa bahwa ibu yang melakukan dan tidak melakukan tes HIV memiliki dukungan suami yang baik (Tabel 1 ).}

Tabel 1. Pengaruh Dukungan Suami dengan Mobilitas Pekerjaan Tinggi dengan Sikap Ibu Hamil di Puskesmas Namorambe Tahun 2019

\begin{tabular}{|c|c|c|c|c|c|c|}
\hline \multirow[t]{3}{*}{ Variabel } & \multicolumn{4}{|c|}{ Keikutsertaan Tes HIV } & \multirow{3}{*}{$\begin{array}{c}p \\
\text { value }\end{array}$} & \multirow{3}{*}{$\begin{array}{c}\text { OR } \\
(95 \% \mathrm{CI})\end{array}$} \\
\hline & \multicolumn{2}{|c|}{ Kasus } & \multicolumn{2}{|c|}{ Kontrol } & & \\
\hline & $\mathbf{n}$ & $(\%)$ & $\mathbf{n}$ & $(\%)$ & & \\
\hline \multicolumn{7}{|l|}{ Sikap } \\
\hline Kurang Baik & 17 & $(54,8)$ & 4 & $(12,9)$ & 0,001 & 8,196 \\
\hline Baik & 14 & $(45,2)$ & 27 & $(87,1)$ & & $(2,311-29,073)$ \\
\hline \multicolumn{7}{|c|}{ Dukungan Suami } \\
\hline Kurang & 15 & $(48,4)$ & 12 & $(38,7)$ & 0,608 & 1,484 \\
\hline Baik & 16 & $(51,6)$ & 19 & $(61,3)$ & & $(0,541-4,072)$ \\
\hline
\end{tabular}

\section{PEMBAHASAN}

Berbagai faktor berpengaruh terhadap tindakan ibu untuk melakukan tes Hiv diantara adalah sikap ibu hamil
Peningkatan akses sarana transportasi dan komunikasi mengakibatkan kemudahan masyarakat untuk melakukan mobilisasi atau perpindahan baik secara vertikal dengan berganti 
profesi dari petani menjadi tenaga buruh pabrik, buruh konstruksi serta secara horizontal karena berpindah tempat tinggal dari desa ke kota. Hal ini menunjukan terjadinya revolusi mobilitas penduduk. Baik mobilitas vertikal akibat perubahan status pekerjaan seseorang maupun mobilitas horizontal akibat berpindahnya seseorang yang melintasi batas wilayah dan waktu tertentu. Kondisi ini juga berdampak pada pola gaya hidup seksual dari masyarakat yang mengarah pada risiko penularan HIV/AIDS (Mackellar, 2005; Jose, 2006; Elisa, 2012 dalam Rokhmah, 2014).

Berdasarkan Chantavanich et al, 2000 (dalam Hugo, 2001) mengindentifikasi beberapa pekerjaan yang berada dalam kelompok migran dengan resiko HIV/AIDS. Salah satunya ialah pekerja di sektor transportasi misalnya pelaut. Dimana adanya hubungan antara tingginya tingkat minuman keras, jauhnya dari keluarga dan keberadaan industri seks di pelabuhan singgah serta rendahnya penggunaan kondom menjadi penyebab tingginya infeksi HIV/AIDS. Selain itu cukup banyak literature tentang hubungan pekerja di sektor transportasi terutama pengemudi truk terhadap penyebaran HIV/AIDS. Jelas disini terjadi hubungan antara pengemudi truk dan bus jarak jauh yang biasanya memiliki pola persinggahan, pemberhentian dan menginap, dan lainlain, yang memberi kesempatan pemanfaatan jasa rumah bordil, terkena dan menyebarkan penyakit, meskipun kurang banyak diketahui tentang perilaku seksual pekerja di sektor transportasi di Indonesia dibandingkan dengan negara lainnnya seperti Thailand, namun jelas bahwasannya jarak panjang di sektor transportasi di Indonesia sangat besar dan potensial menjadi faktor utama penyebaran HIV/AIDS.
Berdasarkan penelitian Ali \& Osman (2014) mengenai faktor-faktor yang mempengaruhi konseling dan tes sukarela HIV pada ibu hamil di Kassala, Sudan Timur menunjukan bahwa tawaran langsung tes HIV dari tenaga kesehatan serta sikap positif dari ibu hamil memiliki dampak yang besar terhadap tindakan untuk melakukan tes HIV, dalam penelitian ini juga tenaga kesehatan melakukan koseling persalinan berbasis rumah, sehingga ibu hamil yang tidak memeriksakan diri ke pelayanan kesehatan juga terpapar terhadap pentingnya melakukan tes HIV ini.

Hasil penelitian ini didukung oleh penelitian Sarumpaet, et.al (2018) mengenai analisis faktor yang berhubungan dengan keikutsertaan ibu hamil dalam pencegahan penularan HIV dari ibu ke bayi menunjukan bahwa ada pengaruh sikap terhadap keikuitsertaan tes HIV dengan $p$ value 0,003 . Terkait dengan hal tersebut maka perempuan harus diberdayakan untuk membuat keputusan tentang tes HIV dan bagaimana menangani stigma dan sikap diskriminatif terhadap orang yang hidup dengan HIV/AIDS harapannya dengan sikap baik yang dimiliki ibu hamil maka dengan kesadaran sendiri ibu hamil mengerti akan pentingnya tes HIV ini dilakukan dan membuat ibu mandiri dalam mengambil keputusan untuk mau melakukan tes HIV.

Berdasarkan penelitian Setiyawaty, et.al (2014) diketahui mengenai sikap ibu rumah tangga terhadap tes HIV/AIDS di Sleman Yogyakarta menyatakan bahwa tes HIV merupakan prosedur wajib dalam pemeriksaan kehamilan untuk antisipasi penularan dan pengobatan yang berorientasi pada kesehatan ibu dan bayinya. Berdasarkan pekerjaan suami pada penelitian ini diketahui bahwa mayoritas memiliki suami dengan pekerjaan buruh luar kota dan sebagian 
supir, militer dan pelayaran. Sehingga responden menyatakan bahwa harus melkaukan tes HIV karena mereka termasuk dalam kelompok risiko tinggi (high risk people) dan kelompok rentan.

Berdasarkan hasil penelitian pada pernyataan mengenai tes HIV diperoleh bahwa responden yang melakukan dan tidak melakukan tes HIV mayoritas telah mendapat penyuluhan dan himbauan dari petugas kesehatan untuk melakukan tes HIV yaitu sebanyak 18 orang $(58,1 \%)$ yang tidak melakukan tes HIV dan 26 orang $(83,9 \%)$ yang melakukan tes HIV.

Berdasarkan hasil penelitian diketahui bahwa responden yang tidak melakukan tes HIV mayoritas tidak setuju bahwa apabila suami bekerja jauh jaraknya dari ibu dan sering berpindah-pindah tempat dalam jangka waktu yang cukup lama memungkinkan ibu rentan terhadap risiko penularan HIV yaitu sebanyak 17 orang (54,8\%). Sedangkan responden yang melakukan tes HIV mayoritas setuju bahwa seorang ibu hamil harus tetap melakukan pemeriksaan tes HIV walaupun tidak ada keluhan yaitu sebanyak 31 orang $(100 \%)$.

Disamping itu pula diketahui bahwa responden yang tidak melakukan tes HIV mayoritas setuju bahwa ibu hamil hanya akan melakukan pemeriksaan tes HIV apabila mendapat persetujuan dari suami yaitu sebanyak 25 orang $(80,6 \%)$. Sedangkan responden yang melakukan tes HIV mayoritas menyatakan tidak setuju bahwa suami bekerja dengan jarak yang tidak jauh dari ibu hamil dan tidak berisiko menularkan virus HIV sehingga bagi ibu hamil tes HIV tidak perlu dilakukan yaitu sebanyak 24 orang (77,4\%).

Berdasarkan hasil penelitian ini dapat diasumsikan bahwa sikap merupakan kesiapan atau kesediaan seseorang untuk bertindak akan tetapi manifestasi sikap belum dapat dilihat secara nyata tetapi hanya dapat ditafsirkan terlebih dahulu dari perilaku tertutup. Sikap didasarkan atas pengetahuan seseorang akan tetapi kembali ada faktor-faktor lain yang berasal dari dalam diri responden maupun faktor yang berasal dari lingkungan sekitar atau yang biasa disebut reaksi terhadap stimulus sosial yang membentuk keyakinan seseorang terhadap sesuatu hal tersebut dan hal ini yang menjadi faktor yang memperkuat kecenderungan seseorang untuk bertindak dan ketersediaan dari layanan kesehatan.

Berdasarkan hasil penelitian diketahui tidak ada hubungan dukungan suami dengan mobilitas pekerjaan tinggi. Hal ini didukung oleh penelitian Halim, et al (2016) mengenai faktorfaktor yang berhubungan dengan perilaku ibu hamil dalam pemeriksaan HIV di Wilayah Kerja Puskesmas Halmahera Kota Semarang yang menunjukan bahwa tidak ada hubungan antara dukungan suami dengan perilaku pemeriksaan HIV. Peran suami yang dimaksud pada penelitian ini dalam mendukung ibu hamil untuk melakukan pemeriksaan HIV yaitu salah satunya dengan mengantar ke pelayanan ANC di puskesmas terdekat. Peran suami juga termasuk menemani selama tes HIV di pelayanan ANC, diskusi mengenai HIV bersama istri dan petugas kesehatan.

Hasil ini berbeda dengan penelitian Sarumpaet, et.al (2018) mengenai analisis faktor yang berhubungan dengan keikutsertaan ibu hamil dalam pencegahan penularan HIV dari ibu ke bayi menunjukan bahwa ada pengaruh dukungan suami terhadap keikutsertaan tes HIV dengan $p$ value 0,001 .

Dalam penelitian tersebut dijelaskan bahwa ketidaksetaraan gender ini juga menyebabkan terjadi ketimpangan kesempatan, partisipasi, 
pengambilan keputusan, pemeliharaan kesehatan, maupun akses lainnya, yang pada akhirnya dapat menimbulkan ketidakadilan gender (gender inequalities). Pandangan berlandaskan gender ini juga ternyata bisa mengakibatkan subordinasi terhadap perempuan. Salah satu konsekuensi dari posisi subordinasi perempuan ini adalah perkembangan keutamaan atas laki-laki dan ketidakberdayaan perempuan dalam mengambil keputusan.

Berbeda dengan penelitian sebelumnya berdasarkan hasil penelitian ini ibu hamil telah bijak mengambil keputusan sendiri terutama mengenai kesehatan tanpa harus tergantung pada keputusan suami, hal ini berarti ibu hamil sudah mulai diberdayakan mengerti mengenai kondisi kesehatan dirinya, bukan saja bertanya terlebih dahulu mengenai suami tetapi tanpa persetujuan suami pun ibu hamil dapat dengan tegas mengambil keputusan. Hal ini juga didukung oleh peran serta dari tenaga kesehatan secara terus menerus terkait dengan tes HIV dalam akses peluang dan kekuatan ibu hamil untuk mengambil keputusan. Dengan demikian pemberdayaan perempuan merupakan aspek penting untuk mencapai kesetaraan gender dan kekuatan dalam pengambilan keputusan terhadap kehidupannya sendiri baik di dalam rumah maupun di luar rumah dan kemampuannya untuk melakukan perubahan terutama peningkatan derajat kesehatan ibu dan bayi.

Berdasarkan hasil penelitian Legiati (2012) mengenai perilaku ibu hamil untuk tes HIV dimana secara statistik ada hubungan antara dukungan suami dengan perilaku tes HIV. Dukungan suami sangat penting dalam hal ini karena masih adanya budaya patriarki, dimana suami merupakan kepala keluarga dan pengambil keputusan dalam keluarganya. Dalam penelitian ini dukungan suami yang paling besar adalah dalam bentuk memberikan izin pada istrinya untuk mengikuti tes HIV, karena dalam hal ini izin suami sangat penting bagi ibu hamil untuk mengikuti tes HIV.

Berdasarkan hasil penelitian pada pernyataan dukungan suami diperoleh bahwa mayoritas responden yang tidak melakukan tes HIV tidak menanyakan pada suami bahwa mereka akan melakukan tes HIV yaitu sebanyak 17 orang $(54,8 \%)$ dan dari 17 orang tersebut ada sebanyak 14 orang $(82,4 \%)$ yang akan melakukan tes HIV tanpa terlebih dahulu menanyakan pada suami. Sedangkan responden yang melakukan tes HIV mayoritas sebelumnya menanyakan pada suami bahwa akan melakukan tes HIV yaitu sebanyak 20 orang $(64,5 \%)$ dan dari 20 orang tersebut ada sebanyak 19 orang $(95,0 \%)$ yang mendapat ijin dari suami untuk melakukan tes HIV.

Disamping itu pula diketahui bahwa responden yang melakukan tes HIV sebelumnya tidak menanyakan pada suami yaitu sebanyak 11 orang $(35,5 \%)$ dan dari 11 orang tersebut mayoritas akan melakukan tes HIV tanpa harus menanyakan pada suami yaitu sebanyak 9 orang $(81,8 \%)$. Mayoritas responden yang tidak melakukan tes HIV menyatakan bahwa motivasi suami merupakan salah satu hal yang memperkuat ibu untuk mau melakukan tes HIV yaitu sebanyak 28 orang $(90,3 \%)$. Sedangkan responden yang ikut serta melakukan tes HIV mayoritas menyatakan bahwa Ibu akan melakukan tes HIV tanpa perlu menanyakan pada suami yaitu sebanyak 22 orang $(71,0 \%)$.

Berdasarkan penelitian Larasaty \& Purwanti (2014) mengenai kajian ibu hamil dalam melakukan Voluntary Counselling (VCT) in health menyatakan 
bahwa suami merupakan salah satu hal yang menjadi alasan bagi mereka untuk melakukan tes HIV, suami selalu memberikan dukungan kepada informan dalam bentuk mengantar dan mendampingi informan ke puskesmas saat akan melakukan pemeriksaan rutin Keputusan suami memang sangatlah penting dalam mendorong ibu untuk mau melakukan tes HIV.Dukungan suami sangat penting bagi ibu dalam memutuskan apakah mau ataupun tidak mau melakukan tes HIV. Selain itu di masyarakat sangat kental dengan konstruksi sosial budaya gender, seperti yang kita ketahui bahwa kultur patriarkhis belum sepenuhnya hilang dalam kehidupan masyarakat saat ini dimana pengambil keputusan dalam sebuah keluarga lebih besar diserahkan kepada suami selaku kepala keluarga.

Tetapi pada penelitian ini kekuatan pengambilan keputusan ada pada ibu hamil, artinya ibu hamil memiliki kesempatan untuk memilih apa yang terbaik bagi kesehatan dirinya sehingga ibu hamil dapat meningkatkan penyerapan pelayanan kesehatan ibu dan pemberdayaan ibu hamil dalam pengambilan keputusan dapat meningkatkan pelayanan kesehatan ibu dan anak.

\section{KESIMPULAN}

Dapat disimpulkan bahwa sikap ibu hamil terbukti berpengaruh terhadap tindakan ibu untuk melakukan tes HIV. Sedangkan dukungan suami dengan mobilitas pekerjaan tinggi terbukti tidak berpengaruh terhadap keikutsertaan tes HIV.

Disarankan kepada petugas kesehatan melakukan upaya peningkatan sikap positif ibu hamil agar lebih diberdayakan dan sadar terhadap kerentanan tertularnya HIV terutama pada ibu dengan mobilitas pekerjaan suami yang tinggi sehingga dapat mengambil keputusan yang tepat terkait dengan pencegahan penularan HIV dari ibu ke bayi lewat tes HIV meskipun belum mendapatkan dukungan dari suami.

\section{DAFTAR PUSTAKA}

Aggleton, P., Bell, S.A., Habku, A.K.(2014). "Mobile Men with Money: HIV Prevention and the Erasure of Difference. The University of New South wales. Glob Public Health Vol 9(3):257270.

DOI: 10.1080/17441692.2014.889736. Diakes tanggal 18 Juni 2019; https://www.ncbi.nlm.nih.gov/pu bmed/24593152

Ali, A.A.A.A., Osman, E. (2014). Factors Influencing HIV Voluntary Counselling and Testing (VCT) among Pregnant Women in Kassala, Eastern Sudan. Journal of Women's Health Care. Vol 3(6). DOI: 10.4172/21670420.1000198. Diakses tanggal $27 \quad$ Juli 201 https://www.longdom.org/openaccess/factors-influencing-hivvoluntary-counseling-and-testingvct-among-pregnant-women-inkassala-eastern-sudan-21670420.1000198.pdf

Halim, Y., BM, S., Kusumawati, A. (2016). Faktor-Faktor yang berhubungan dengan Perilaku Ibu Hamil dalam Pemeriksaan HIV di Wilayah Kerja Puskesmas Halmahera Kota Semarang. Jurnal Kesehatan Masyarakat (e-journal) Vol. 4(5). ISSN: 2356-3346.

Hugo, G. (2001). Mobilitas Penduduk dan HIV/AIDS di Indonesia, diakses tanggal 17 Juni 2019; http://web.unair.ac.id/admin/file/ f_66426_wcms_141795.pdf 
Kementerian Kesehatan RI. (2018). Data dan Informasi Profil Kesehatan Indonesia 2017.

Larasaty, N.D, Purwanti, I.A. (2014). Kajian Niat Ibu Hamil dalam Melakukan Voluntary Counselling and Testing (VCT) di Puskesmas Kota Semarang. Fakultas Kesehatan Masyarakat Universitas Muhammadiyah Semarang

Legiati, T.PS., Suryoputro, A., Shaluhiyah, Z. (2012). Perilaku Ibu Hamil untuk Tes HIV di Kelurahan Bandarharjo dan Tanjung Mas Kota Semarang. Jurnal Promosi Kesehatan Indonesia. Vol. 7(2), diakses tanggal 18 Juni 2019; https://ejournal.undip.ac.id/index .php/jpki/article/view/5560/4942

Peraturan Menteri Kesehatan Kesehatan R.I. 2017. Eliminasi Penularan Human Immunodeficiency Virus, Sifilis dan Hepatitis B dari Ibu ke Anak. Diakses tanggal 09 Agustus 2018;

http://hukor.kemkes.go.id/upload s/produk_hukum/PMK_No._52_tt g_Eliminasi_Penularan_HIV,_Sifili
S,_dan_Hepatitis_B_Dari_Ibu_Ke _Anak_.pdf

Rokhmah, D. (2014). Implikasi Mobilitas Penduduk dan Gaya Hidup Seksual terhadap Penularan HIV/AIDS, Jurnal Kesehatan Masyarakat. Vol. 9(2), diakses tanggal 23 Juni 2019;

http://journal.unnes.ac.id/artikel_ nju/kemas/2847

Sarumpaet, S., Hutahaean, M.M., Zaluchu, F. (2018). An Analysis of Factors Affecting Woman's Use of Prevention of Mother to Child Transmission Services in Urban Setting. Indian Journal of Public Health Research \& Development. Vol 9(10): 197-202.

Setiyawati,N., Shaluhiyah,S., Cahyo, K. (2014) Sikap Ibu Rumah Tangga terhadap Tes HIV/AIDS di Sleman Yogyakarta. Jurnal Promosi Keshetan Indonesia Vol 9(1): 5666. Diakes tanggal 18 Juli 2019; https://media.neliti.com/media/p ublications/126065-ID-sikap-iburumah-tangga-terhadap-teshiva.pdf 